\title{
HIV Risk Perceptions and First Sexual Intercourse Among Youth in Cape Town, South Africa
}

By Kermyt G. Anderson, Ann M.

Beutel and Brendan Maughan-Brown

Kermyt G. Anderson is assistant professor,

Department of Anthropology, University of Oklahoma, Norman,

OK, USA. Ann M. Beutel is assistant professor, Department of Sociology, University of Oklahoma.

Brendan MaughanBrown is doctoral candidate, AIDS and Society Research Unit, Centre for Social Science Research, University of Cape Town, South Africa.

CONTEXT: HIV prevalence is high among South African youth. Health behavior models posit that the perceived level of risk of HIV infection is associated with the level of HIV risk behavior; however, there has been limited research in Sub-Saharan Africa on factors associated with perceived risk or on the relationship between perceived risk and risk behaviors.

METHODS: Longitudinal data collected in 2002 and 2005 from 3,017 black, colored and white youth in Cape Town, South Africa, were analyzed using multivariate regression to examine whether a reciprocal relationship exists between sexual experience and perceived HIV risk. Independent variables taken from the 2002 survey were used to predict dependent variables taken from the 2005 survey.

RESULTS: In 2005, most youth (82\% of males and $83 \%$ of females) viewed themselves as being at no or small risk of HIV infection. A reciprocal relationship in which higher perceived HIV risk was associated with a delay in sexual debut (odds ratio, 0.8) and sexual experience was associated with higher perceived risk (1.4) was found for females, but not for males. Knowing someone who had died of AIDS was associated with sexual debut and with an elevated perceived HIV risk among females (1.7 and 1.3, respectively). The associations between race and perceived risk of HIV infection varied by gender.

CONCLUSIONS: HIV/AIDS education and prevention programs should consider more carefully how gender and race may intersect to influence risk perceptions and risk behaviors. In addition, possible reciprocal relationships between risk behaviors and risk perceptions should be considered in education and intervention programs.

International Family Planning Perspectives, 2007, 33(3):98-105

HIV risk behavior and prevalence remain critical health concerns in South Africa, particularly among youth, whose HIV prevalence is $10 \% .^{1}$ A number of models used to explain health behavior posit that high perceived risk is associated with low levels of risk-taking behavior. ${ }^{2-5}$ Although some studies in Sub-Saharan African countries have considered perceived risk as a predictor of such risk behaviors as using condoms inconsistently or having multiple sex partners, ${ }^{6-11}$ relatively few studies have focused explicitly on the predictors of perceived risk of HIV infection. In addition, most studies of HIV risk perceptions and risk behaviors have used cross-sectional data, making it difficult to disentangle the causal relationship between risk perceptions and risk behaviors.

This article examines the relationship between HIV risk perceptions and an important risk behavior, first sexual intercourse, using two waves of data from the Cape Area Panel Study (CAPS), a representative survey of youth in Cape Town, South Africa. We use time-lagged variables to examine whether a reciprocal relationship exists between perceived risk and having had sex-specifically, whether perceived risk among sexually inexperienced youth predicts the timing of first sex, and whether having had sex influences subsequent perceived risk. In addition, we consider whether knowing someone who has died of AIDS influences the tim- ing of first sex or the level of perceived HIV risk, and whether factors associated with first sex and perceived HIV risk vary by gender.

\section{First Sexual Intercourse and HIV Risk Perceptions}

In South Africa, as in many other developing countries, the primary method of HIV transmission is heterosexual intercourse, ${ }^{12}$ and most South African youth know that HIV can be transmitted this way. ${ }^{1,13}$ Among South Africans aged 15-24, more than half have had sex by age $18 .{ }^{1}$ Although not all sex is risky sex (e.g., the probability of HIV infection is reduced if condoms are used consistently or if individuals have only one, uninfected sexual partner), engaging in first sex is the entry point to subsequent risk behavior. Thus, compared with youth who initiate sex at an early age, youth who delay sex spend fewer years of their lives at risk of HIV infection. For this reason, first sexual intercourse is considered an HIV risk behavior.

Despite high HIV prevalence and high rates of sexual risk behaviors in South Africa and other Sub-Saharan African countries, young people in these countries often perceive themselves as being at low risk of HIV infection. ${ }^{9,14-19}$ One explanation for this is that youth may underestimate risks in general because of a feeling of invulnerability. ${ }^{15,20} \mathrm{Ad}$ ditionally, HIV and AIDS are highly stigmatized in South 
Africa. ${ }^{21,22}$ Because acknowledging one's own risk admits the possibility of being part of a stigmatized group, youth may avoid this by downplaying their personal risk. ${ }^{15}$

We expect to find a reciprocal relationship between HIV risk perception and sexual initiation; that is, sexually inexperienced youth who perceive themselves to be at high risk will be more likely than those who perceive themselves to be at lower risk to delay first sexual intercourse, and individuals who have had sex will perceive themselves at higher risk than those who are sexually inexperienced. One may question whether sexually inexperienced youth can have any perceived risk of HIV infection. However, sexually inexperienced youth may perceive themselves to be at risk if, for example, they doubt their ability to maintain consistent condom use or to identify partners who are at low risk of infection once they become sexually active. ${ }^{15}$ In previous research in KwaZulu-Natal (a South African province with a high HIV prevalence), some youth with no HIV risk behaviors nonetheless perceived themselves as at risk of infection within the next 12 months. ${ }^{15}$ Sexually inexperienced youth who view themselves as at risk of HIV infection at some point in the future may try to delay first sex-the gateway to further HIV risk behaviors.

Most research on the relationship between HIV risk perceptions and risk behaviors in Sub-Saharan Africa has looked at such variables as condom use and number of sexual partners. These studies have produced mixed results, with some finding correlations between HIV risk perceptions and risk behaviors $8,9,11,14,18,23$ and others finding none. ${ }^{6}$ Relatively little research in Sub-Saharan Africa has examined first sexual intercourse as a risk behavior associated with perceived HIV risk. Some cross-sectional research indicates that individuals may remain sexually inexperienced out of concerns about HIV infection, ${ }^{24,25}$ and one crosssectional study found greater perceived risk among young females who had had sex. ${ }^{23}$

Gender, race and personal experience with HIV/AIDS are variables that may be important for both risk behaviors (including entry into first sex) and perceived risk. Personal experience and familiarity with HIV/AIDS may be associated with more awareness of infection pathways, less stigma toward the disease and higher perceived risk of HIV infection. Many young South Africans know about HIV/AIDS firsthand: Among South Africans aged 15-24, 26\% know someone living with HIV, and 45\% know someone who has died of AIDS. ${ }^{17}$ Yet, studies have found either no relationship between risk behaviors and knowing someone living with HIV or someone who has died of AIDS, or a relationship in some groups but not others. ${ }^{11,26,27}$ Evidence of a relationship between knowing someone living with HIV or someone who has died of AIDS and greater perceived risk among young people in Africa has also been mixed. ${ }^{14,15,28}$

There are important gender differences in HIV prevalence and sexual risk behaviors in South Africa. Among those aged $15-24,16 \%$ of females and 5\% of males are seropositive. ${ }^{17}$ Compared with females, males are more likely to report hav- ing used condoms at first or last sex. ${ }^{17,25}$ Median age at first sex does not differ by gender, ${ }^{25}$ but the predictors of first sex may, as research in other Sub-Saharan African countries has found. ${ }^{29}$ Evidence about the relationship between gender and perceived risk is mixed. 7,9,14,15,17,28 Even if the absolute levels of risk are similar for males and females, research on African youth has found that some correlates of perceived HIV risk, including HIV/AIDS knowledge and sexual risk behaviors, do vary by gender. ${ }^{14,15,23}$

Race is particularly important in South Africa, in part because of the legacy of apartheid, the former policy of strict racial segregation. Under apartheid, coloreds (people of mixed race) and Indians (Asians) were moderately disadvantaged relative to whites (people of European descent), and blacks (Africans) were severely disadvantaged. Although apartheid ended by the mid-1990s, racial inequality and de facto segregation continue. ${ }^{30-32}$ Among youth, HIV prevalence varies by race (blacks, 12\%; coloreds, 2\%; and whites and Indians, $1 \%$ or less). ${ }^{1}$ Engagement in HIV risk behaviors also varies by race: For example, the median age at first sex for blacks is 16.5 years, compared with 17.5 for whites, coloreds and Indians. ${ }^{25}$ Furthermore, blacks are less likely than others to report consistent condom use with their most recent partner. ${ }^{17,25}$ With few exceptions, ${ }^{15,18,23}$ little attention has been paid to racial or ethnic differences in the level of perceived HIV risk and the predictors of perceived risk among youth in South Africa or other African countries.

Other background factors that may be associated with sexual initiation and perceived HIV risk include age and education. Older youth are more likely than younger youth to have had sex. In addition, a positive relationship between age and perceived risk has been found for young people in South Africa, ${ }^{15}$ but not in other African countries. ${ }^{14,18}$ Education may be an important protective factor, leading to a later age at first sex and higher HIV risk perceptions. ${ }^{14,33-35}$

\section{METHODS}

We used data from Wave 1 and Wave 3 of the Cape Area Panel Study (CAPS), a longitudinal study designed to follow the lives of a large representative sample of youth in metropolitan Cape Town as they undergo transitions from adolescence to adulthood. ${ }^{36 *}$ CAPS used two main sources of data: a household questionnaire about the schooling, employment and fertility of all household members, and a youth questionnaire about the schooling, employment, sexual behavior and fertility of household members aged 14-22 in 2002.

\section{Data}

CAPS used a two-stage probability sample of households. The first-stage sample of census enumeration areas was drawn using the 1996 census as a sampling frame. Because enumeration areas in South Africa are generally homoge-

*The second (2003-2004) wave of the study reinterviewed only a subset of the original sample and did not ask any questions about perceived HIV risk. 
neous with respect to race, black and white areas were oversampled to obtain roughly equal numbers of black, colored and white youth. The second stage randomly sampled households within each selected enumeration area. Within each recruited household, a household survey was administered to one adult who was knowledgeable about the household and full-length youth questionnaires were given separately to up to three young people.

The first wave of CAPS, conducted in 2002, includes data from 5,256 households (42\% black, 44\% colored and 14\% white) and 4,752 youth (45\% black, $40 \%$ colored and $16 \%$ white). ${ }^{*}$ The response rates for households with youth were higher for blacks (89\%) and coloreds (82\%) than for whites (48\%); the response rates for youth in participating households were high for all groups, ranging from $93 \%$ for blacks to $86 \%$ for whites.

The third wave was conducted in 2005, and contains data from 3,536 youth and 2,412 households. The overall retention rate for youth who participated in the first wave was $75 \%$; youth retention varied by racial group, with higher rates among blacks (70\%) and coloreds (85\%) than among whites (60\%). In 2005, household questionnaires were administered only to households containing youth who had completed the youth questionnaire administered that year. Virtually all of these households (92-95\%) also completed the household questionnaire.

The lower response rates for whites than nonwhites in our sample were not unexpected, as they are typical of survey research in South Africa. ${ }^{1,17}$ Whites may perceive participation in the survey as having higher opportunity costs, reducing their likelihood of involvement. For all racial groups, moving away from Cape Town was the primary reason for nonresponse in the 2005 wave of the study; the greater movement of white youth than of black and colored youth out of Cape Town was the main reason for their lower retention rate. ${ }^{36}$ Our sample of whites may thus be biased against households and youth for whom participating in the study had greater opportunity costs, and against youth who moved away from the study area.

\section{Measures}

To avoid endogeneity issues, we utilized a lagged independent variables approach in which independent variables measured in Wave 1 (2002) were used to predict dependent variables measured in Wave 3 (2005). In one set of

*Only 27 respondents-less than $1 \%$ of the entire sample-belonged to another racial group and were dropped from the analysis.

tIn preliminary analyses, the highest grade the respondent had completed by Wave 1 was included as a measure of both education and socioeconomic background. This variable was not significant in any models, and dropping it did not change any of the results. Therefore, we excluded the variable from later analyses.

‡Entry into first sexual intercourse could be examined using event history analysis, treating each year between Wave 1 and Wave 3 as a separate unit of analysis for risk of first sex. However, we had few appropriate timevarying independent variables to use for such an analysis. In particular, our main independent variables of interest-perceived HIV risk and knowledge of someone who had died of AIDS-did not vary with time. Therefore, we felt that logistic regression was a more appropriate analytical approach for this outcome. analyses, the dependent variable was whether youth had had first sexual intercourse by Wave 3, among those who were sexually inexperienced at Wave 1. In a second set of analyses, the dependent variable was perceived HIV risk at Wave 3, among all youth who had completed surveys at both time points.

Sexual experience was measured with a dichotomous variable indicating whether the respondent had ever had sexual intercourse (defined as "full penetration"). We included a measure based on respondents' answers at Wave 1 as an independent variable to predict perceived HIV risk measured at Wave 3 for the full sample (i.e., all respondents, regardless of sexual experience at Wave 1). We included a measure based on respondents' answers at Wave 3 as a dependent variable to measure transition to first sex for the Wave 1 sexually inexperienced sample.

We measured perceived risk of HIV infection with the question, "Do you think you have no risk, a small risk, a moderate risk or a great risk of getting the AIDS virus?"; this question was asked in both waves. Because the question did not specify a time frame, youth may have considered both their short-term and long-term chances of HIV infection when they reported their perceived risk. We included a measure based on respondents' answers at Wave 1 as an independent variable in the set of analyses predicting first sex by Wave 3 among respondents who had been sexually inexperienced at Wave 1; we used a measure based on the Wave 3 version as the dependent variable in the second set of analyses, for the full sample of youth.

Personal experience with HIV/AIDS was measured in Wave 1 by the question, "Do you personally know anyone who has died or you think has died of HIV/AIDS?" The respondent's age, measured at Wave 1, was coded in years. Gender was captured by a dummy variable, coded as 0 for females and 1 for males. Race was coded using dummy variables for coloreds and whites, with blacks as the reference category. Education was measured using a dichotomous variable that indicated whether the respondent was enrolled in school at the time of the survey (Wave 1 or Wave 3, depending on the analysis). ${ }^{\dagger}$

\section{Analysis}

For our analyses, we restricted the sample to youth who had completed both the Wave 1 and Wave 3 interviews. We excluded 206 youth who had ever been married, because married persons are likely to have different patterns of risk behavior and different perceptions of HIV risk than those who are unmarried. ${ }^{35}$ In addition, we excluded respondents with missing data and those who answered "don't know." Our final sample consisted of 3,017 youth, including 1,779 who were sexually inexperienced at Wave 1.

We used logistic regression to estimate the likelihood of youth who were sexually inexperienced at Wave 1 having had sex by Wave $3{ }^{\dagger}{ }^{*}$ controlling for perceived HIV risk, personal experience with HIV/AIDS, gender, race, age and school enrollment status, all measured at Wave 1 . We then 
used ordinal logit regression to examine perceived HIV risk at Wave 3. This technique is similar to logistic regression; however, it allows for more than two ordinal outcome levels, which was necessary because the dependent variable had four outcome levels. We analyzed HIV risk perceptions as a function of the respondent's lifetime sexual experience, personal experience with HIV/AIDS, gender, race and age, all measured at Wave 1, as well as the respondent's school enrollment status at Wave 3. For each dependent variable, two sets of models were estimated: the first for all youth and the second separately by gender.

Analyses were performed in Stata/SE 9.1, adjusting standard errors to account for the complex survey design. When weighted for oversampling of blacks and whites, and for nonresponse of households and youth, the results are representative of metropolitan Cape Town.

\section{RESULTS}

\section{Descriptive Analyses}

Among the full sample of youth, the mean age at Wave 1 for both males and females was 17.7 years (Table 1). Twenty-eight percent of males were black, 53\% colored and 19\% white; the proportions for females were 29\%, 51\% and 21\%. About two-fifths of both males and females (39\% and $42 \%$, respectively) were enrolled in school at Wave 3. Seventeen percent of males and 20\% of females reported at Wave 1 that they knew someone who had died of AIDS. About twofifths (39\% of males and 36\% of females) of respondents had had sex by Wave 1 . The level of perceived HIV risk reported at Wave 3 was fairly low: Among males, 44\% perceived no risk and 39\% small risk; the proportions among females were $47 \%$ and $36 \%$, respectively. Only $7 \%$ of males and females perceived themselves as being at great risk of HIV infection.

Among youth who were sexually inexperienced at Wave 1 , the mean age for both males and females was 16.7 years. Nineteen percent of males were black, $57 \%$ colored and $24 \%$ white; the proportions for females were $21 \%, 58 \%$ and $21 \%$. The vast majority of both males and females ( $81 \%$ and $84 \%$, respectively) were enrolled in school at Wave 1. Eleven percent of males and $17 \%$ of females reported at Wave 1 that they knew someone who had died of AIDS. Nearly half of respondents (47\% of males and $45 \%$ of females) who were sexually inexperienced at Wave 1 had had sex by Wave 3. The level of perceived HIV risk reported was fairly low: Among males, 58\% perceived no risk and 31\% small risk; the proportions among females were $60 \%$ and $29 \%$, respectively. Only 5\% of males and females perceived their risk as great.

In both samples, a greater proportion of females than of males reported knowing someone who had died of AIDS. In addition, several racial differences in risk perceptions were found in the sexually inexperienced sample (not shown): A greater proportion of blacks (84\%) than of coloreds (58\%) or whites (39\%) perceived no risk, whereas a greater proportion of coloreds (6\%) than of blacks (5\%) or whites (3\%) perceived great risk.
TABLE 1. Characteristics of 14-22-year-olds who participated in both Wave 1 and Wave 3 of the Cape Area Panel Study, by gender and sexual experience at Wave 1

\begin{tabular}{lll|ll} 
& All & & \multicolumn{2}{l}{ Sexually inexperienced } \\
\cline { 2 - 5 } Characteristic & $\begin{array}{l}\text { Male } \\
(\mathrm{N}=1,429)\end{array}$ & $\begin{array}{l}\text { Female } \\
(\mathrm{N}=1,588)\end{array}$ & $\begin{array}{l}\text { Male } \\
(\mathrm{N}=813)\end{array}$ & $\begin{array}{l}\text { Female } \\
(\mathrm{N}=966)\end{array}$ \\
\hline Age at Wave 1 & $17.7(0.07)$ & $17.7(0.08)$ & $16.7(0.01)$ & $16.7(0.08)$ \\
Race & & & & \\
$\quad$ Black & 27.7 & 28.7 & 18.8 & 21.1 \\
$\quad$ Colored & 53.2 & 50.6 & 57.4 & 58.0 \\
$\quad$ White & 19.0 & 20.7 & 23.8 & 21.0 \\
Enrolled in school at Wave 1 & na & na & 81.2 & 83.9 \\
Enrolled in school at Wave 3 & 39.0 & 41.7 & na & na \\
At Wave 1, knew someone who & & & & \\
$\quad$ had died of AIDS & 16.5 & $19.8^{*}$ & 11.4 & $16.9 * * *$ \\
Ever had sex at Wave 1 & 38.9 & 36.0 & na & na \\
Ever had sex at Wave 3 & na & na & 46.6 & 45.1 \\
Perceived HIV risk at Wave 1 & & & & \\
$\quad$ No risk & na & na & 57.6 & 59.9 \\
$\quad$ Small risk & na & na & 31.0 & 28.6 \\
Moderate risk & na & na & 6.5 & 6.4 \\
$\quad$ Great risk & & na & 4.9 & 5.1 \\
Perceived HIV risk at Wave 3 & 43.6 & 47.3 & na & na \\
$\quad$ No risk & 38.8 & 35.9 & na & na \\
Small risk & 10.9 & 10.2 & na & na \\
Moderate risk & 6.8 & 6.6 & na & na \\
Great risk & & & &
\end{tabular}

${ }^{*} \mathrm{p}<.05 .{ }^{* * *} \mathrm{p}<.001$. Notes: Data are percentages, unless otherwise noted. Figures in parentheses are standard errors. na=not applicable.

\section{Multivariate Analyses}

Among youth, older age at Wave 1 was associated with elevated odds of having had sex by Wave 3 (odds ratio, 1.2Table 2). Gender was not associated with sexual experience but race was, with coloreds and whites being less likely than blacks to have had sex by Wave 3 ( 0.3 each); there was no significant difference between whites and coloreds (not shown). Respondents who were enrolled in school at Wave 1 had lower odds than those who were not to have had sex between waves (0.6). Neither knowing someone who had died of AIDS nor HIV risk perception at Wave 1 was associated with having had sex between waves.

When separate analyses were conducted by gender, cer-

\begin{tabular}{|c|c|c|c|}
\hline Characteristic & $\begin{array}{l}\text { All } \\
(\mathrm{N}=1,779)\end{array}$ & $\begin{array}{l}\text { Male } \\
(\mathrm{N}=813)\end{array}$ & $\begin{array}{l}\text { Female } \\
(\mathrm{N}=966)\end{array}$ \\
\hline Age at Wave 1 & $1.18(0.04)^{* * * *}$ & $1.19(0.06)^{* * *}$ & $1.18(0.06)^{* * * *}$ \\
\hline \multicolumn{4}{|l|}{ Gender } \\
\hline Female (ref) & 1.00 & na & na \\
\hline Male & $1.10(0.13)$ & na & na \\
\hline \multicolumn{4}{|l|}{ Race } \\
\hline Black (ref) & 1.00 & 1.00 & 1.00 \\
\hline Colored & $0.26(0.04)^{* * *}$ & $0.31(0.07)^{* * *}$ & $0.22(0.04)^{* * *}$ \\
\hline White & $0.26(0.05)^{* * * *}$ & $0.27(0.08)^{* * *}$ & $0.26(0.07)^{* * *}$ \\
\hline \multicolumn{4}{|l|}{ Enrolled in school at Wave 1} \\
\hline No (ref) & 1.00 & 1.00 & 1.00 \\
\hline Yes & $0.58(0.12)^{* *}$ & $0.52(0.15)^{*}$ & $0.67(0.18)$ \\
\hline \multicolumn{4}{|c|}{ At Wave 1, knew someone who had died of AIDS } \\
\hline No (ref) & 1.00 & 1.00 & 1.00 \\
\hline Yes & $1.24(0.22)$ & $0.83(0.22)$ & $1.70(0.34)^{* *}$ \\
\hline Perceived HIV risk at Wave 1 & $0.88(0.07)$ & $0.99(0.10)$ & $0.78(0.08)^{*}$ \\
\hline$F$ & 28.28 & 12.55 & 19.18 \\
\hline
\end{tabular}

${ }^{*} p<.05 .{ }^{* *} p<.01 .{ }^{* * *} p<.001$. Notes: ref $=$ reference group. na=not applicable. 
tain variables were significant among females but not among males, and vice versa. For example, females who reported at Wave 1 knowing someone who had died of AIDS were more likely than those who had not to have had sex by Wave 3 (odds ratio, 1.7). Also, among females, a higher perceived risk of HIV at Wave 1 was negatively associated with sexual initiation between waves (0.8).

In ordinal logistic regression analyses of perceived HIV risk measured at Wave 3 for the full sample (i.e., all youth, regardless of sexual experience at Wave 1), all variables were significant, except the respondent's gender and school enrollment status (Table 3). Perceived risk rose with age, although the finding was only marginally significant. Compared with blacks, whites perceived themselves to be at higher risk (odds ratio, 1.3); perceived risk among coloreds was not significantly different from that among blacks. (In supplementary analyses that are not shown, both blacks and coloreds had significantly lower perceived risk than whites.) Youth who had reported at Wave 1 that they knew someone who had died of AIDS perceived a higher risk at Wave 3 than those who had not (1.3). Finally, being sexually experienced at Wave 1 was associated with elevated perceived risk at Wave 3 (1.5).

When we conducted analyses separately by gender, most results were similar to those for the full sample. For example, having had sex by Wave 1 was associated with higher perceived HIV risk at Wave 3 among both males and females (odds ratios, 1.5 and 1.4, respectively). In addition, knowing someone who had died of AIDS was associated with higher perceived risk for both males and females ( 1.3 each), although the finding was only marginally significant for males. Some results, however, varied by gender. Perceived risk rose with age for females (1.1), but not for males. The effects of race also varied somewhat by gender. Among males, colored and white youth had greater perceived HIV risk at Wave 3 than black youth (1.5 and 1.8, respectively);

\begin{tabular}{|c|c|c|c|}
\hline Characteristic & $\begin{array}{l}\text { All } \\
(\mathrm{N}=3,017)\end{array}$ & $\begin{array}{l}\text { Male } \\
(\mathrm{N}=1,429)\end{array}$ & $\begin{array}{l}\text { Female } \\
(\mathrm{N}=1,588)\end{array}$ \\
\hline Age at Wave 1 & $1.04(0.02) \dagger$ & $1.03(0.04)$ & $1.06(0.03)^{*}$ \\
\hline \multicolumn{4}{|l|}{ Gender } \\
\hline Female (ref) & 1.00 & na & na \\
\hline Male & $1.14(0.10)$ & na & na \\
\hline \multicolumn{4}{|l|}{ Race } \\
\hline Black (ref) & 1.00 & 1.00 & 1.00 \\
\hline Colored & $0.92(0.09)$ & $1.53(0.21)^{* *}$ & $0.56(0.08)^{* * *}$ \\
\hline White & $1.30(0.15)^{*}$ & $1.80(0.29)^{* * *}$ & $0.95(0.15)$ \\
\hline \multicolumn{4}{|c|}{ Enrolled in school at Wave 3} \\
\hline No (ref) & 1.00 & 1.00 & 1.00 \\
\hline Yes & $1.13(0.11)$ & $1.00(0.15)$ & $1.24(0.17)$ \\
\hline \multicolumn{4}{|c|}{ At Wave 1 , knew someone who had died of AIDS } \\
\hline No (ref) & 1.00 & 1.00 & 1.00 \\
\hline Yes & $1.28(0.12)^{*}$ & $1.27(0.18) \dagger$ & $1.31(0.17)^{*}$ \\
\hline \multicolumn{4}{|c|}{ Ever had sex at Wave 1} \\
\hline No (ref) & 1.00 & 1.00 & 1.00 \\
\hline Yes & $1.49(0.15)^{* * *}$ & $1.48(0.21)^{* *}$ & $1.44(0.21)^{*}$ \\
\hline$F$ & 7.98 & 5.39 & 10.78 \\
\hline
\end{tabular}

additional analyses indicated that perceived risk did not differ significantly between coloreds and whites (not shown). Among females, however, colored but not white respondents perceived their risk as lower than did blacks (0.6); in additional analyses, coloreds perceived lower risk than did whites (not shown). To investigate race and gender further, we analyzed a model of the pooled sample using combined race-gender dummies and found every race-gender group but one-black males-had a higher perceived risk than colored females (not shown).

\section{DISCUSSION}

Consistent with previous research, ${ }^{9,14-19}$ we found that a majority of the youth in our study perceived themselves as being at little or no risk of HIV infection. In addition, we found evidence among females of a reciprocal relationship between risk perception and sexual experience. Specifically, perceiving a greater risk of HIV infection in 2002 was associated with a lower probability of becoming sexually active between 2002 and 2005, and being sexually experienced by 2002 was associated with greater perceived HIV risk in 2005. Thus, our results for females provide some support for health behavior models positing that greater perceived risk is associated with fewer risk-taking behaviors.

For males, although sexual experience was associated with HIV risk perception, the reverse was not true: Perceived HIV risk was not associated with males' sexual debut between surveys. Gender-based beliefs, pressures, roles and power may influence the ability of males and females to behave in ways that correspond to their risk perceptions. Females might realize that once they become sexually active, they may have less control than males ${ }^{37,38}$ in terms of condom use and other protective behaviors, thereby increasing their chances of becoming infected with HIV. Also, young women might worry about becoming pregnant and transmitting HIV to a baby. ${ }^{39}$ Thus, young females who are more concerned about their risk of HIV may try to delay first sex. Furthermore, support from parents and others may help females more than males to keep their sexual behaviors in line with their risk perceptions. ${ }^{15}$ Among males, in contrast, the widespread belief that males "need" sex and the strong peer pressure they face to have sex ${ }^{16,19}$ may be more important influences on sexual behavior than perceived HIV risk.

Another variable associated with sexual debut among females, but not among males, was knowing someone who had died of AIDS. Factors not controlled for in our research might account for this gender difference. For example, the importance of certain groups of individuals on males' and females' sexual behaviors may vary. Knowing someone who had died of AIDS might be a more important influence on the sexual behaviors of females than males, whereas peers might be a more important influence on the sexual behaviors of males than females. More research is needed to understand why the association between personal experience with HIV/AIDS and sexual debut vary by gender.

We found important variations by race and gender in sexual debut and perceived risk. Blacks were more likely 
than whites or coloreds to have had first sex between surveys; supplemental analyses did not reveal gender differences in the odds of first sex within any racial group. Furthermore, whites were more likely than blacks and coloreds to perceive themselves as being at risk of HIV infection; however, when this finding was examined separately by gender for each race, colored or white males perceived greater risk than did black males, while colored females perceived lower risk than white or black females. This suggests a racegender interaction, with colored females having the lowest perceived HIV risk.

Our results underscore the importance of race and ethnicity for HIV/AIDS-related attitudes, perceptions and risk behaviors of South African youth. Race is a complex issue, and may function as a proxy for a host of social and cultural factors, including discrimination, sources of knowledge and information, beliefs about the origins of HIV, AIDSrelated stigma and the meaning of sexuality. The lack of attention to social and cultural factors in models used to explain perceptions and behavior related to HIV/AIDS in South Africa has been noted elsewhere. ${ }^{16,19,40}$ Our findings suggest that different aspects of race and gender may intersect to influence risk perceptions and behaviors.

\section{Limitations}

Our study had a number of limitations. First, attrition in our longitudinal dataset may have resulted in bias, especially with respect to highly mobile youth and youth for whom participation in survey research had the highest costs (i.e., those with jobs or in school). Second, the two waves of data were collected three years apart, which is a relatively long interval for studying relationships that might be highly variable over time. The few studies of young people in South Africa and other African countries that used longitudinal data had less time between waves of data collection than our study did, but these studies were usually evaluations of intervention programs using nonrepresentative samples of youth. ${ }^{41,42}$ More longitudinal studies of HIV risk perceptions and risk behaviors using representative samples of youth are needed.

\section{Program Implications}

Our findings suggest that sexual debut is an important risk behavior influencing risk perception among youth in Cape Town. One explanation for this finding is that HIV/AIDS education programs may be having an impact on risk perception: Young people may be absorbing the message that abstinence influences HIV risk.

Although many HIV/AIDS education and prevention programs in South Africa attempt to reach a wide range of individuals (e.g., males and females; sexually experienced and inexperienced; and individuals from different population groups), our results suggest that education and prevention programs should pay even more attention to developing culturally sensitive ways to reach youth. In particular, prevention programs may need to acknowledge that perceived risk varies for groups defined by both race and gender. We recognize the enormous cost and effort involved in implementing such a strategy, but a one-size-fitsall policy may be less effective at changing perceptions and behaviors.

Our findings may also have implications for education and intervention programs targeted at female youth. For example, our results for females suggest that education programs that help females align their risk perceptions with the realities of HIV/AIDS in South Africa may lead to less risk-taking behavior (e.g., delayed engagement in first sex).

In conclusion, our results suggest that the relationships among perceived HIV risk, personal experience with HIV/AIDS and HIV risk behaviors are complex and dynamic. HIV/AIDS education and prevention programs in South Africa should take into account how the experiences and specific social situations of youth may influence their attitudes, perceptions and behaviors.

\section{REFERENCES}

1. Shisana O et al., South African National HIV Prevalence, HIV Incidence, Behaviour and Communication Survey, 2005, Cape Town, South Africa: Human Sciences Research Council Press, 2005.

2. Ajzen I and Fishbein M, Understanding Attitudes and Predicting Social Behavior, Englewood Cliffs, NJ, USA: Prentice Hall, 1980.

3. Bandura A, Social cognitive theory and exercise of control over HIV infection, in: DiClemente RJ and Peterson JL, eds., Preventing AIDS: Theories and Methods of Behavioral Interventions, New York: Plenum Press, 1994.

4. Catania J, Kegeles S and Coates T, Toward an understanding of risk behavior: an AIDS risk reduction model (ARRM), Health Education Quarterly, 1990, 17(1):53-72.

5. Janz N and Becker M, The health belief model: a decade later, Health Education Quarterly, 1984, 11(1):1-47.

6. Adetunji J and Meekers D, Consistency in condom use in the context of HIV/AIDS in Zimbabwe, Journal of Biosocial Science, 2001 33(1):121-138

7. Boer H and Mashamba MT, Psychosocial correlates of HIV protection motivation among black adolescents in Venda, South Africa, AIDS Education and Prevention, 2005, 17(6):590-602.

8. Maharaj P, Reasons for condom use among young people in KwaZuluNatal: prevention of HIV, pregnancy or both? International Family Planning Perspectives, 2006, 32(1):28-34.

9. Maswanya ES et al., Knowledge, risk perception of AIDS and reported sexual behavior among students in secondary schools and colleges in Tanzania, Health Education Research, 1999, 14(2):185-196.

10. Simbayi LC et al., Risk factors for HIV-AIDS among youth in Cape Town, South Africa, AIDS and Behavior, 2005, 9(1):53-61.

11. Ukwuani FA, Tsui AO and Suchindran CM, Condom use for preventing HIV infections/AIDS in Sub-Saharan Africa: a comparative multilevel analysis of Uganda and Tanzania, Journal of Acquired Immune Deficiency Syndromes, 2003, 34(2):203-213.

12. UNAIDS, 2006 Report on the Global AIDS Epidemic, New York: United Nations Publications, 2006.

13. Eaton L and Flisher AJ, HIV/AIDS knowledge among South African youth, Southern African Journal of Child and Adolescent Mental Health, 2000, 12(2):97-124.

14. Barden-O'Fallon JL et al., Factors associated with HIV/AIDS knowledge and risk perception in rural Malawi, AIDS and Behavior, 2004, 8(2):131-140.

15. Macintyre K et al., Understanding perceptions of HIV risk among adolescents in KwaZulu-Natal, AIDS and Behavior, 2004, 8(3):237-250. 16. MacPhail C and Campbell C, 'I think condoms are good but, aai, I 
hate those things': condom use among adolescents and young people in a Southern African township, Social Science \& Medicine, 2001, 52(11):1613-1627.

17. Pettifor AE et al., HIV and Sexual Behaviour among Young South Africans: A National Survey of 15-24 Year Olds, Johannesburg, South Africa: Reproductive Health Research Unit, University of Witwatersrand, 2004.

18. Sarker M et al., The role of HIV-related knowledge and ethnicity in determining HIV risk perception and willingness to undergo HIV testing among rural women in Burkina Faso, AIDS and Behavior, 2005, 9(2):243-249

19. Tillotson J and Maharaj P, Barriers to HIV/AIDS protective behavior among African adolescent males in township secondary schools in Durban, South Africa, Society in Transition, 2001, 32(1):83-100.

20. Moore $S$ and Rosenthal D, Adolescent invulnerability and perceptions of AIDS risk, Journal of Adolescent Research, 1991, 6(2):164-180.

21. Kalichman SC et al., Development of a brief scale to measure AIDSrelated stigma in South Africa, AIDS and Behavior, 2005, 9(2):135-143.

22. Maughan-Brown BG, Attitudes towards people with HIV/AIDS: stigma and its determinants among young adults in Cape Town, South Africa, South African Review of Sociology, 2006, 37(2):165-188.

23. Shobo Y, Youth's perceptions of HIV infection risk: a sex-specific test of two risk models, African Journal of AIDS Research, 2007, 6(1):1-8.

24. Gersovitz M, The HIV epidemic in four African countries seen through the Demographic and Health Surveys, Journal of African Economies, 2005, 14(2):191-246.

25. Simbayi LC, Chauveau J and Shisana O, Behavioural responses of South African youth to the HIV/AIDS epidemic: a nationwide survey, AIDS Care, 2004, 16(5):605-618.

26. Camlin CS and Chimbwete CE, Does knowing someone with AIDS affect condom use? An analysis from South Africa, AIDS Education and Prevention, 2003, 15(3):231-244

27. Macintyre K, Brown L and Sosler S, It is not what you know, but who you knew: examining the relationship between behavior change and AIDS mortality in Africa, AIDS Prevention and Education, 2001 13(2):160-174

28. Smith RA and Morrison D, The impact of stigma, experience, and group referent on HIV risk assessments and HIV testing intentions in Namibia, Social Science \& Medicine, 2006, 63(10):2649-2660.

29. Gupta N and Mahy M, Sexual initiation among adolescent girls and boys: trends and differentials in Sub-Saharan Africa, Archives of Sexual Behavior, 2003, 32(1):41-53.

30. Burgard SA and Treiman DJ, Trends and racial differences in infant mortality in South Africa, Social Science \& Medicine, 2006 62(5):1126-1137.

31. Burger R and Woolard I, The State of the Labour Market in South Africa After the First Decade of Democracy, Centre for Social Science Research Working Papers, Cape Town, South Africa: University of Cape Town, 2005, No. 133

32. Charasse-Pouélé $C$ and Fournier M, Health disparities between racial groups in South Africa: a decomposition analysis, Social Science \& Medicine, 2006, 62(11):2897-2914

33. Magnani RJ et al., Reproductive health risk and protective factors among youth in Lusaka, Zambia, Journal of Adolescent Health, 2002, 30(1):76-86.

34. Slonim-Nevo V and Mukuka L, AIDS-related knowledge, attitudes and behavior among adolescents in Zambia, AIDS and Behavior, 2005 , 9(2):223-231.

35. Zambuko $\mathrm{O}$ and Mturi AJ, Sexual risk behaviour among the youth in the era of HIV/AIDS in South Africa, Journal of Biosocial Science, 2005, 37(5):569-584.

36. Lam D, Seekings J and Sparks M, The Cape Area Panel Study (CAPS): Overview and Technical Documentation for Waves 1-2-3, Cape Town, South Africa: Centre for Social Research, University of Cape Town, 2006.

37. Campbell $\mathrm{C}$ and MacPhail C, Peer education, gender and the de- velopment of critical consciousness: participatory HIV prevention by South African youth, Social Science \& Medicine, 2002, 55(2):331-345.

38. Eaton L, Flisher AJ and Aarø LE, Unsafe sexual behavior in South African youth, Social Science \& Medicine, 2003, 56(1):149-165.

39. Rutenberg N et al., Pregnant or positive: adolescent childbearing and HIV risk in KwaZulu Natal, South Africa, Reproductive Health Matters, 2003, 11(22):122-133.

40. Hartell CG, HIV/AIDS in South Africa: a review of sexual behavior among adolescents, Adolescence, 2005, 40(157):171-181.

41. Gallant M and Maticka-Tyndale E, School-based HIV prevention programmes for African youth, Social Science \& Medicine, 2004, 58(7):1337-1351

42. Speizer IS, Magnani RJ and Colvin CE, The effectiveness of adolescent reproductive interventions in developing countries: a review of the evidence, Journal of Adolescent Health, 2003, 33(5):324-348.

\section{RESUMEN}

Contexto: La prevalencia de VIH es alta entre la gente joven sudafricana. Los modelos de conducta relativos a la salud proponen que el nivel percibido de riesgo de infección por VIH está asociado con el nivel de conductas sexuales de riesgo; sin embargo, es limitada la investigación que se ha realizado en África subsahariana sobre factores asociados con el riesgo percibido, o sobre la relación entre riesgo percibido y conductas de riesgo.

Métodos: Se analizó un conjunto de datos longitudinales recolectados en 2002 y 2005 respecto a 3,017 jóvenes de raza negra, mestiza (población de origen indio, chino y otros) y blanca en Ciudad del Cabo, Sudáfrica, utilizando regresión multivariada para examinar si existía una relación recíproca entre la experiencia sexual y el riesgo percibido de VIH. Algunas variables independientes tomadas de la encuesta de 2002 se utilizaron para predecir variables dependientes tomadas de la encuesta de 2005

Resultados: La mayoría de las personas jóvenes (82\% de los hombres y $83 \%$ de las mujeres) se percibieron a sí mismas fuera de riesgo o con poco riesgo de infección por VIH en 2005. Se encontró para las mujeres, pero no para los hombres, una relación recíproca en la que un mayor riesgo percibido de VIH se asoció con un retraso en el debut sexual (razón de momios, 0.8) y la experiencia sexual se asoció con un mayor riesgo percibido (1.4). Conocer a alguien que había muerto de SIDA se asoció con haber tenido experiencia sexual y con un elevado riesgo percibido de VIH entre las mujeres (1.7 y 1.3, respectivamente). Las asociaciones entre raza y riesgo percibido variaron según el género.

Conclusiones: Los programas de educación y prevención del VIH y SIDA deben considerar más cuidadosamente la forma en que el género y la raza pueden entrecruzarse para influir en las percepciones y conductas de riesgo. Adicionalmente, debe tomarse en consideración las posibles relaciones recíprocas entre las conductas de riesgo y las percepciones de riesgo en los programas de educación e intervención.

\section{RÉSUMÉ}

Contexte: La prévalence du VIH est élevée parmi les jeunes d'Afrique du Sud. Selon les modèles de comportement de santé, le niveau de risque perçu en ce qui concerne l'infection à VIH serait associé au niveau de comportement à risques. La recherche 
relative aux facteurs associés au risque perçu et au rapport entre le risque perçu et les comportements à risques est cependant limitée en Afrique subsaharienne.

Méthodes: Les données longitudinales recueillies en 2002 et 2005 auprès de 3.017 jeunes noirs, métis et blancs de Cape Town, en Afrique du Sud, ont été analysées par régression multivariable afin de déterminer l'existence ou non d'un rapport réciproque entre l'expérience sexuelle et le risque perçu de contraction du VIH. Les variables indépendantes de l'enquête de 2002 ont servi à prédire celles dépendantes de la version 2005.

Résultats: La plupart des jeunes (82\% des hommes et $83 \%$ des femmes) estimaient courir un risque tout au plus minime de contraction du VIH en 2005. Un rapport réciproque, dans lequel un plus grand risque perçu était associé à un accès différé à la sexualité active (rapport de probabilitiés, 0,8) et l'expérience sexuelle était associée à un plus grand risque perçu $(1,4)$, a été observé chez les jeunes femmes, mais pas chez leurs homologues masculins. La connaissance d'une personne morte du sida s'est révélée associée à l'experience sexuel et à un haut risque perçu de contraction du VIH parmi les filles (1.7 et 1.3, respectivement). Les associations entre la race et le risque perçu varient en fonction du sexe.

Conclusions: Les programmes d'information et de prévention $\mathrm{du} \mathrm{VIH} /$ sida doivent envisager avec plus d'attention l'intersection éventuelle entre le sexe et la race dans les perceptions du risque et les comportements à risques. Ces programmes doivent en outre tenir compte des rapports réciproques possibles entre les comportements à risques et les perceptions du risque.

\section{Acknowledgments}

The Cape Area Panel Study Waves 1-2-3 were collected between 2002 and 2005 by the University of Cape Town and the University of Michigan, with funding provided by the U.S. National Institute for Child Health and Human Development and the Andrew W. Mellon Foundation.

Author Contact:kganders@ou.edu 